\title{
Binge drinking: in search of its molecular target via the $\mathrm{GABA}_{A}$ receptor
}

\author{
Andrew R. S. T. Yang ${ }^{1}$, Juan Liu ${ }^{2}$, Heon S. Yi ${ }^{1}$, Kaitlin T. Warnock ${ }^{1}$, Mingfei Wang ${ }^{1}$, Harry L. June Jr. ${ }^{1}$, \\ Adam C. Puche ${ }^{3}$, Ahmed Elnabawi ${ }^{4}$, Werner Sieghart ${ }^{5}$, Laure Aurelian ${ }^{2 *}$ and Harry L. June Sr. ${ }^{1,2 *}$ \\ Neuropsychopharmacology Laboratory, Department of Psychiatry, Division of Alcohol and Drug Abuse, School of Medicine, University of Maryland, Baltimore, \\ MD, USA \\ 2 Department of Pharmacology and Experimental Therapeutics, School of Medicine, University of Maryland, Baltimore, MD, USA \\ ${ }^{3}$ Department of Anatomy and Neurobiology, School of Medicine, University of Maryland, Baltimore, MD, USA \\ ${ }^{4}$ Department of Epidemiology and Preventive Medicine, School of Medicine, University of Maryland, Baltimore, MD, USA \\ ${ }^{5}$ Division of Biochemistry and Molecular Biology, Center for Brain Research, Medical University of Vienna, Vienna, Austria
}

\section{Edited by:}

A. Leslie Morrow, University of North Carolina School of Medicine, USA

\section{Reviewed by:}

Patricia H. Janak, University of California, San Francisco, USA Jeff Weiner, Wake Forest University Baptist Medical Center, USA

\section{*Correspondence:}

Laure Aurelian, Laboratory of Virology/Immunology, Department of Pharmacology and Experimental

Therapeutics, University of Maryland School of Medicine, 655 West

Baltimore Street, BRB 4-023,

Baltimore, MD 21201, USA.

e-mail: laurelia@umaryland.edu;

Harry L. June Sr., Division of Alcohol

and Drug Abuse, Department of

Psychiatry, University of Maryland

School of Medicine, 4th

Floor-04-019, 110 South Paca Street,

Baltimore, MD 212101, USA.

e-mail: hjune@psych.umaryland.edu
Binge drinking, frequently referred to clinically as problem or hazardous drinking, is a pattern of excessive alcohol intake characterized by blood alcohol levels $\geq 0.08 \mathrm{~g} \%$ within a 2 -h period. Here, we show that overexpression of $\alpha 1$ subunits of the $G_{A B A}$ receptor contributes to binge drinking, and further document that this involvement is related to the neuroanatomical localization of $\alpha 1$ receptor subunits. Using a herpes simplex virus amplicon vector to deliver small interference RNA (siRNA), we showed that siRNA specific for the $\alpha 1$ subunit (pHSVsiLA1) caused profound, long-term, and selective reduction of gene expression, receptor density, and binge drinking in high-alcohol drinking rats when delivered into the ventral pallidum (VP). Scrambled siRNA (pHSVsiNC) delivered similarly into the VP failed to alter gene expression, receptor density, or binge drinking. Silencing of the a1 gene in the VP, however, failed to alter binge sucrose or water intake. These results, along with our prior research, provide compelling evidence that the $\alpha 1$-containing GABA $A$ receptor subunits are critical in the regulation of binge-like patterns of excessive drinking. Collectively, these data may be useful in the development of gene-based and novel pharmacological approaches for the treatment of excessive drinking.

Keywords: alcohol, binge drinking, $\mathrm{GABA}_{A}$ receptor, siRNA, viral vector, $\mathrm{HAD}$ rat, ventral pallidum, alpha 1

\section{INTRODUCTION}

Of the total US population 21 years and older, $23 \%$ are binge drinkers and $76 \%$ of the alcohol consumed in the US is in the form of binge drinking [National Survey on Drug Use and Health (NSDUH), 2002]. The adverse consequences include increased risk of developing alcohol dependence, particularly during adolescence (Hingson and Zha, 2009), and a significant increase in the risk for hypertension, cardiomyopathy, alcohol poisoning, sexually transmitted diseases, liver disease, and brain damage (Crews and Braun, 2003; Naimi et al., 2003; Townshend and Duka, 2005). Perhaps the most devastating societal cost of binge drinking is a substantial proportion of alcohol-related deaths in the form of vehicle crashes [Chikritzhs et al., 2001; Center for Disease Control, and Prevention (CDCP), 2004], making binge drinking the third leading preventable cause of death in the US. Because the proportion of drinkers that binge is highest among 18- to 20-year-olds (72\%; NSDUH, 2002), young drinkers contribute substantially to these fatalities (CDCP, 2004). Hence, binge drinking is an enormous public health burden in need of more radical treatment approaches.
Novel gene therapies, which target candidate receptors linked to excessive alcohol drinking, may offer potential alternatives to psychosocial and pharmacotherapeutic interventions for treating binge drinking. The $\gamma$-amino butyric acid- ${ }_{-A}\left(G_{A B A}\right)$ receptors may represent such a therapeutic target (Koob, 2004; June and Eiler, 2007; Harris et al., 2008; Kumar et al., 2009). Of the potential $\mathrm{GABA}_{\mathrm{A}}$ receptors, substantial evidence implicates the al subunit-containing receptors in regulating excessive alcohol drinking (Harvey et al., 2002; June et al., 2003; June and Eiler, 2007). Thus, pharmacological studies demonstrate that microinfusion of $\alpha 1$-preferring ligands into the ventral pallidum (VP, a locus containing the highest concentrations of $\alpha 1$ subunits within the reward circuitry; Churchill et al., 1991) selectively regulates excessive alcohol drinking (June et al., 2003; Harvey et al., 2002; June and Eiler, 2007). Furthermore, the GABA-enhancing effects of alcohol in the VP were positively correlated with binding of the $\alpha 1$ selective agonist $\left[{ }^{3} \mathrm{H}\right]$ zolpidem, and increased zolpidem binding has been reported in the VP of alcohol-preferring rats (Criswell et al., 1995; Devaud et al., 1995). Finally, two lines of $\alpha 1$ knock-out [KO] mice evidence markedly decreased alcohol drinking (Boehm et al., 2004; June et al., 2007). 
While the above evidence suggests that $\mathrm{GABA}_{\mathrm{A}} \alpha 1$-containing receptors of the VP may play a role in excessive alcohol drinking, their direct role in mediating binge drinking when blood alcohol concentration $(\mathrm{BAC}) \geq 0.08 \mathrm{mg} \%$ (National Institute on Alcohol Abuse, and Alcoholism, 2004; Bell et al., 2006) was only documented by our recent report (Liu et al., 2011). In that study, we reported that downregulation of the GABA $\alpha 1$ receptor subunit gene in the VP resulted in a selective and profound reduction in binge drinking in $\mathrm{P}$ rats. In the present study, we sought to further understand the role that the $\alpha 1$ receptor subunit plays in binge drinking by examining its capacity to regulate the behavior in the high-alcohol drinking (HAD) rat line. The HAD line has been suggested as a model of human alcohol abuse (McBride and Li, 1998), but has not been characterized as extensively as the P rat (Bell et al., 2006). As with the $P$ rat in the effort-related operant model (Liu et al., 2011), we posited that the $\alpha 1$ receptor subunit selectively regulates volitional home-cage binge drinking in $\mathrm{HAD}$ rats.

To begin testing our hypothesis, we first examined innate levels of the $\alpha 1$ receptor protein in the $\mathrm{VP}$ and in other reward loci of $\mathrm{HAD}$ and LAD rats, which have disparate alcohol drinking phenotypes (McBride and Li, 1998). While we recently reported that the VP was associated with binge alcohol drinking, and that $\mathrm{P}$ rats exhibited significantly higher levels of the $\alpha 1$ subunit protein relative to NP rats at this site (Liu et al., 2011), we also considered the possibility that levels of the $\alpha 1$ subunit within other alcohol reward loci such as the extended amygdala (EA) and basolateral amygdala (BLA; Koob, 2004; Koob and Le Moal, 2005) could also be associated with excessive alcohol intake. The EA comprises the bed nucleus of the stria terminalis (BST), the central nucleus of the amygdala (CeA), and the shell of the nucleus accumbens (NAcc;
Heimer and Alheid, 1991). The BLA is a projection locus for several EA loci; it sends reciprocal projections to the VP (Heimer and Alheid, 1991), and, like the EA, primarily contains $\alpha 2$ receptor subtypes. Substantial evidence suggests that neuroadaptive changes in both the EA and the VP, may be linked to motivation for excessive/binge alcohol drinking (Koob and Le Moal, 2005; Stephens and Duka, 2008; Liu et al., 2011). Finally, because the EA and related loci contain high levels of the $\alpha 2$ receptor subunit (Pirker et al., 2000; Kaufmann et al., 2003), and we have previously shown that $\alpha 2$ receptor subunits regulate binge drinking in $P$ rats, at least in the CeA (Liu et al., 2011), we also investigated the possibility that higher levels of the $\alpha 2$ subunit could be observed in HAD relative to $\mathrm{LAD}$ rats in these putative alcohol reward loci.

\section{RESULTS}

HAD RATS EXPRESS ELEVATED LEVELS OF THE GABA $A_{A} \alpha 1$ SUBUNIT IN THE VP AND CeA THAN THEIR LAD COUNTERPARTS

Duplicates of punch biopsies obtained from distinct neuroanatomical sites (VP, CeA, BLA, and BST) of HAD and LAD rats were immunoblotted with $\alpha 1$ - or $\alpha 2$-specific antibodies, with results quantitated by densitometric scanning as previously described (Smith et al., 1998; Liu et al., 2011). Levels of $\alpha 1$ in $\mathrm{HAD}$ rats were significantly higher in the VP (Figure 1A) and CeA (Figure 1B) than in LAD rats, but the two lines expressed similar levels of $\alpha 1$ in the BLA and BST (Figures 1C,D). These findings are in direct contrast to those obtained for the $\alpha 2$ receptor subunit, the levels of which were similar for HAD and LAD rats at all the examined anatomical sites (Figures 1E-H). Our previous report in $\mathrm{P}$ rats also revealed an elevation in $\alpha 1$ subunits in the $\mathrm{VP}$ and CeA (Liu et al., 2011).
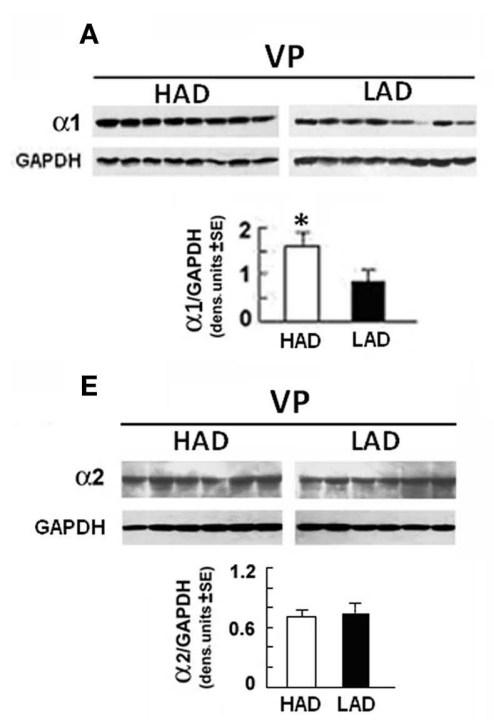
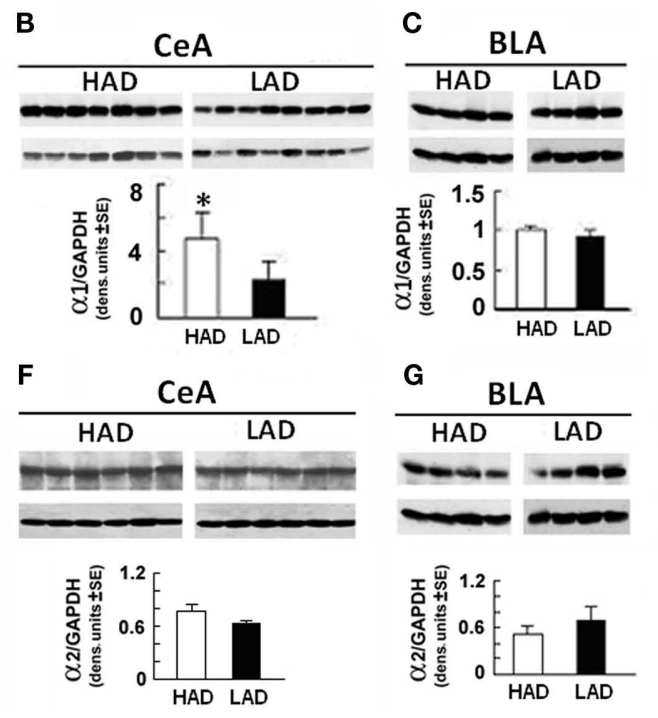
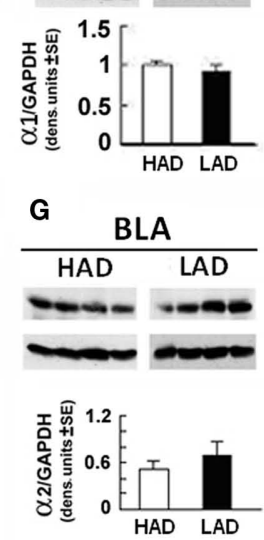
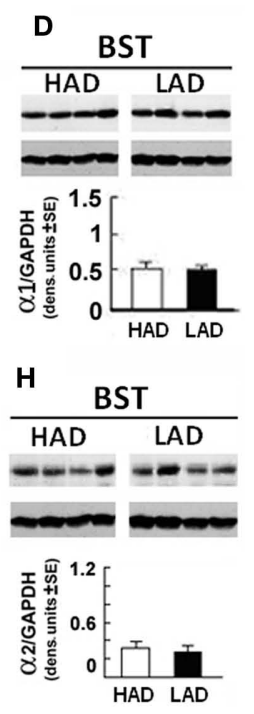

FIGURE 1 | $\alpha 1$ expression is increased in the ventral pallidum (VP) and central amygdaloid nucleus (CeA) from HAD as compared with LAD rats. Micropunch samples were collected from the right and left hemispheres of rats and pooled. Protein extracts were immunoblotted with antibodies specific for the $\mathrm{GABA}_{\mathrm{A}} \alpha 1$ (A-D) or $\alpha 2$ (E-H) subunits, using GAPDH antibody as control. Quantitation was done by densitometric scanning; each lane represents a distinct animal. The levels of $\alpha 1$ were significantly higher in the $\operatorname{VP}[F(1,14)=15.15$, $P<0.002]$ (A) and $\operatorname{CeA}[F(1,13)=71.51, P<0.001]$ (B) from HAD than $L A D$ rats. The levels of $\alpha 1$ in the basolateral amygdaloid nucleus [BLA; (C)] and bed nucleus of the stria terminalis (BST) (D), as well as the levels of $\alpha 2$ at all these sites (E-H), were similar between HADs and LADs. The Newman-Keuls post hoc followed each significant between-group ANOVA. ${ }^{*} P<0.001$. 


\section{HSV-BASED VECTORS DELIVER SIRNA TO SPECIFIC NEUROANATOMICAL SITES}

Having seen that $\alpha 1$ is overexpressed in the VP and CeA, we wanted to know whether it is associated with vulnerability to engage in binge alcohol drinking. We focused on the VP to determine if the findings observed in $\mathrm{P}$ rats could be extrapolated to HAD rats in a volitional model of binge alcohol drinking. It should also be noted that overexpression of $\alpha 1$ in the CeA of $\mathrm{P}$ rats failed to regulate binge drinking, in contrast to similar overexpression in the VP (Liu et al., 2011). These findings indicate that overexpression of the $\alpha 1$ subunit in the CeA in and of itself is not sufficient to regulate the neuroadaptional processes associated with binge drinking.

In the present study, we employed the siRNA technology to examine the contribution of the $\alpha 1$ subunit to binge drinking, as it provides a mechanism for inhibiting specific genes at individual loci. The sequence and specificity of the $\alpha 1$ siRNA used in these studies and the construction of the HSV-based vector for its delivery (pHSVsiLA1), have been described previously (Liu et al., 2011). pHSVsiNC, a scrambled siRNA sequence delivered with a similar HSV-based vector, was studied in parallel with pHSVsiLA1 as a specificity control. Both vectors express enhanced green fluorescent protein (EGFP) in order to facilitate their detection following delivery.

As described in the Section "Materials and Methods," vectors were delivered into the VP by bilateral stereotaxic microinfusion, and transduction was assessed by confocal microscopy at $72 \mathrm{~h}$ post delivery by EGFP visualization. The image shown in Figure 2A for 1 of the 13 bilateral injection sites in the VP of a HAD rat given pHSVsiLA1 (Figure 2B) indicates that transduction was effective, with substantial clusters of transduced neurons seen near the injection site. We conclude that most EGFP-positive cells contain $\mathrm{GABA}_{\mathrm{A}}$ receptors, because $90 \%$ of the synapses in the VP are GAD immunoreactive, and $\alpha 1$ is the most highly expressed $\mathrm{GABA}_{\mathrm{A}}$ subunit in the VP (Churchill et al., 1991; Pirker et al., 2000).
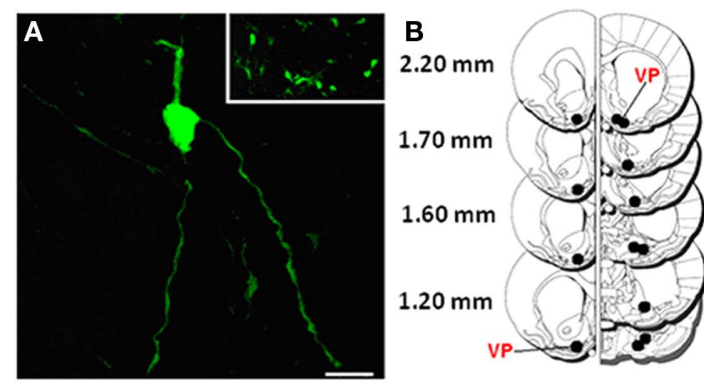

$0.70 \mathrm{~mm}$

$0.50 \mathrm{~mm}$ $0.20 \mathrm{~mm}$ $-0.30 \mathrm{~mm}$ $-0.40 \mathrm{~mm}$ $-0.80 \mathrm{~mm}$

FIGURE 2 | Visualization represents low magnification of amplicon infected cells in the VP using confocal microscopy. (A) LoW

magnification showing a group of infected cells near 1 of the 13 bilateral VP (black) injection sites in (B); also depicted in high magnification is an individual neuron expressing the EGFP tag. Scale bar represents $25 \mu \mathrm{m}$ in (A) and $250 \mu \mathrm{m}$ in the insert. (B) Histological mapping of control and pHSVsiLA1 amplicon infusions across the VP, with coronal sections at +2.20 to $-0.80 \mathrm{~mm}$ from bregma (Paxinos and Watson, 1998). Black dots indicate the bilateral stereotaxic infusion sites across the VP (red).

\section{pHSVsiLA1 SPECIFICALLY INHIBITS $\alpha 1$ EXPRESSION AT THE SITE AT WHICH IT IS INJECTED}

To examine whether $\alpha 1$ expression is specifically inhibited by pHSVsiLA1, cohorts of HAD rats were given pHSVsiLA1, pHSVsiNC, or PBS in the VP, with levels of $\alpha 1$ protein determined at 3 days post-infusion via immunoblotting of duplicate sections with $\alpha 1$-specific antibody. Alpha-2-specific antibody was used as a control. pHSVsiLA1 caused a robust decrease in $\alpha 1$ levels relative to those in the PBS-treated animals, a finding that was not observed in HAD rats given pHSVsiNC (Figure 3A). Moreover, the levels of the $\alpha 2$ subunit were not altered (Figure 3B), consistent with the conclusion that $\alpha 1$ reduction is not secondary to compensatory increases in another subunit, notably $\alpha 2$, in the same tissues. Particularly significant from the standpoint of therapy, $\alpha 1$ expression was still significantly inhibited on day 17 after pHSVsiLA1 infusion, albeit at a less profound level than on day 3 post-infusion (Figure 3C), underscoring the specificity and protracted duration of pHSVsiLA1's inhibitory effect. The long-term effect of pHSVsiLA1, at least in this animal model, is not an artifact of the experimental procedures. Alpha-2 expression was unchanged (Figure 3D), and levels of $\alpha 1$ expression on day 30 after pHSVsiLA1 infusion were similar to those observed both pre-surgery and for animals given PBS or pHSVsiNC (Figure 3E).

\section{REDUCED $\alpha 1$ EXPRESSION IN pHSVsiLA1-, BUT NOT pHSVsINC-TREATED CELLS, EXTENDS TO PROTEIN LEVELS ON THE CELL SURFACE AS DETERMINED BY IMMUNOBLOTTING OF BIOTINYLATED PROTEINS}

The cell culture data summarized in Figure 4 indicate that approximately $50 \%$ of the total $\alpha 1$ protein levels are biotinylated (i.e., expressed on the cell surface). Identical levels of biotinylated $\alpha 1$ protein were seen in cells treated with pHSVsiNC; however, treatment with pHSVsiLA1 caused a significant decrease in levels of biotinylated $\alpha 1$ protein. The data indicate that inhibition of $\alpha 1$ expression by pHSVsiLA1 also causes a significant reduction in surface protein expression.

\section{pHSVsiLA1-INDUCED $\alpha 1$ INHIBITION DECREASES THE DENSITY OF THE GABA $_{\mathbf{A}}$ RECEPTOR}

Because pHSVsiLA1 specifically reduced $\alpha 1$ gene expression, including on the surfaces of cells, we wanted to know whether it interferes with the density of the $\mathrm{GABA}_{\mathrm{A}}$ receptor. $\mathrm{HAD}$ rats were given pHSVsiLA1 or PBS in the VP and tissues were collected at 3 days after infusion, when levels of $\alpha 1$ expression are significantly decreased. The collected VP tissues were assayed for radioligand binding of $\left[{ }^{3} \mathrm{H}\right] \mathrm{EBOB}$, a specific radioligand for the non-competitive convulsant blocking site of the GABA receptor, as previously described (Korpi et al., 1995). Binding was significantly reduced in the pHSVsiLA1-treated rats, as revealed by competition of picrotoxin with $\left[{ }^{3} \mathrm{H}\right] \mathrm{EBOB}$ (Figure 5). A saturation isotherm showed significant differences in specific binding between the group given pHSVsiLAl $(n=10)$ relative to the PBS group $(n=10)$. $\left[{ }^{3} \mathrm{H}\right] \mathrm{EBOB}$ binding (B $\left.\max \right)$ was profoundly reduced from $861 \pm 16 \mathrm{fmol} / \mathrm{mg}$ protein in the control to $554 \pm 8 \mathrm{fmol} / \mathrm{mg}$ protein in the pSHVsiLAl-treated rats, with no significant change in affinity $\left(K_{\mathrm{d}}\right.$; control, $2.67 \pm 0.24 \mathrm{nM}$; pSHVsiLA1, $2.70 \pm 0.18 \mathrm{nM}$; Figures 5A,B). Reduced binding 

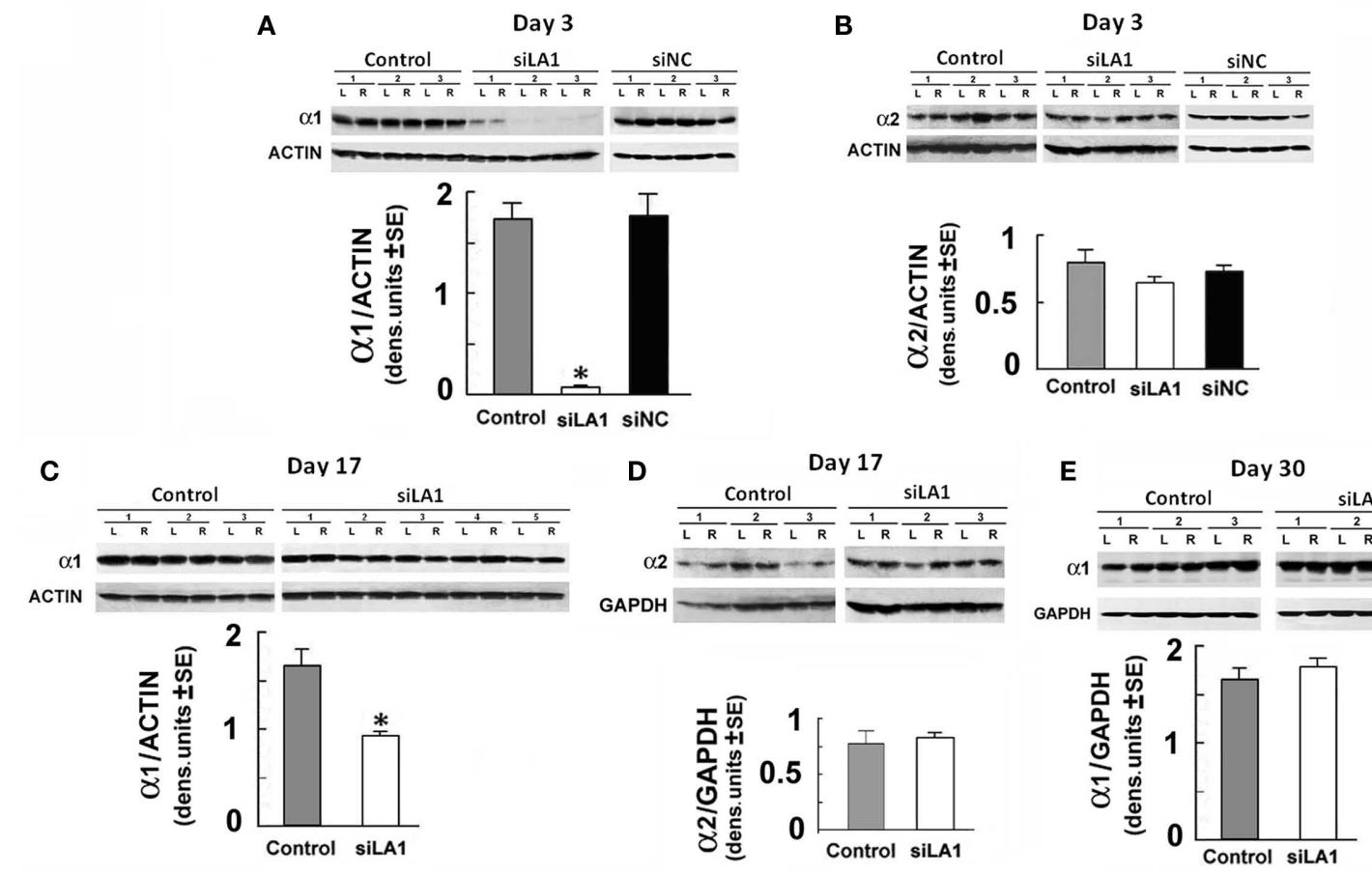

FIGURE 3 | pHSVsiLA1 inhibits $\alpha \mathbf{1}$ expression in the VP. Micropunch samples of HAD rats given PBS (control), pHSVsiLA1, or pHSVsiNC ( $n=3$ each) into the VP by stereotaxic microinfusion were collected from the VP tissues on days $3(\mathbf{A}, \mathbf{B}), 17$ (C,D) or 30 (E) after infusion and assayed for gene expression by immunoblotting. Quantitation was done by densitometric scanning, and data are expressed as the mean \pm SEM. Each well represents a sample of tissue from the left $(L)$ or right $(R)$ hemisphere of one animal; the levels of protein reduction were symmetrical in both the left $(\mathrm{L})$ and right $(\mathrm{R})$ hemispheres; hence, the data were pooled. (A) Immunoblotting with $\alpha 1$ antibody at 3 days post-infusion indicates that levels of $\alpha 1$ protein were significantly lower in rats given pHSVsiLA1 (siLA1) than PBS $[F(2,15)=173.43, P<0.001]$, but similar $\alpha 1$ levels were seen in rats given PBS and pHSVsiNC (siNC). (B) Duplicates of the tissues used for (A) were immunoblotted with a2-specific antibody, with no significant group effects. (C,D) VP tissues from HAD rats given PBS $(n=3)$ or pHSVsiLA1 ( $n=5, n=3$ respectively) as in $(\mathbf{A}, \mathbf{B})$ were immunoblotted with $\alpha 1$ or $\alpha 2$ antibodies at 17 days after infusion. $\alpha 1$ expression was still significantly lower in the pHSVsiLA1-treated rats $[F(1,14)=16.66$,

$P<0.001]$. Immunoblotting with $\alpha 2$ antibody did not differentiate between the PBS and pHSVsiLA1-treated rats, and pHSVsiNC did not reduce $\alpha 1$ expression relative to PBS (data not shown). (E) Immunoblotting of VP tissues collected on day 30 after infusion indicated similar levels of $\alpha 1$ expression in PBS and pHSVsiLA1-treated rats. Significant effects were identified using the Tukey post hoc test; ${ }^{*} P<0.001$. levels evidenced after pHSVsiLA1 treatment (64\% of control levels) correlate well with the reductions in $\alpha 1$ protein expression on the cell surface ( $50 \%$ of control levels; Figure 4). A similar reduction was not seen in any of the neuroanatomical sites of the PBS control rats that were not injected with the virus, nor in animals given pHSVsiNC or pHSVsiLA1 at sites that do not express high levels of $\alpha 1$ (data not shown), confirming the specificity of the pHSVsiLA1-mediated inhibition. Collectively, the data summarized in Figures 3-5 indicate that use of vector-delivered siRNA allows for specific inhibition of gene expression in one targeted neuroanatomical site, thereby providing the means to examine its contribution to alcohol drinking.

VP-DELIVERED pHSVsiLA1 INHIBITS ALCOHOL DRINKING IN HAD RATS Having seen that pHSVsiLA1 specifically inhibits $\alpha 1$ expression and reduces the density of the $\mathrm{GABA}_{\mathrm{A}}$ receptor in the $\mathrm{VP}$, we wanted to know whether this reduction is associated with inhibition of binge alcohol drinking. Cohorts of HAD rats $(n=5-6$ per group) were trained to self-administer alcohol (Bell et al., 2006; Integrative Neuroscience Initiative on Alcoholism (INIA)West, 2008) and randomly administered, by cohort, pHSVsiLA1, pHSVsiNC, or PBS into the VP. After 3 days, during which the animals recovered from the stress of surgery, they were allowed to engage in daily alcohol drinking for 30 days. The results of these studies are summarized in Figure 6. In the rats given pHSVsiLA1, alcohol drinking was virtually eliminated on days 3-6 after infusion, when $\alpha 1$ expression was robustly inhibited. Drinking was still profoundly reduced by comparison to the PBS-treated animals on days 7-17 after pHSVsiLA1 infusion, when $\alpha 1$ expression was still inhibited. From days 18-26 the pHSVsiLA1-treated animals tended to show a daily elevation in responding. However, their intake levels were significantly lower compared with the control animals. By days 26-30 there was no differentiation in ethanol administration observed between the pHSVsiLA1 and control groups (Figure 6A). However, the precise time at which protein expression returned to pre-surgery levels in the pHSVsiLA1-treated animals is unknown. At 17 days post-infusion, $\alpha 1$ expression was significantly attenuated relative to control-treated animals, albeit markedly above that of animals $72 \mathrm{~h}$ post-treatment. At present, we are investigating the protracted time-course of protein reduction vis-à-vis reduction in volitional alcohol intake following administration of the $\alpha 1$ siRNA amplicon into the VP, in order to more precisely determine the significance of the relationship between the two. Nevertheless, we propose that the 
effect of pHSVsiLA1 is specific for alcohol, because water ingestion was similar between rats treated with pHSVsiLA1 or PBS control throughout the study interval (Figure 6B), and because the effects of pHSVsiLA1 was undistinguishable from those of PBS in HAD rats trained to drink sucrose in an analogous model (Figure 6C). We conclude that inhibition of alcohol intake by pHSVsiLA1 is related to $\alpha 1$ inhibition in the VP. This is not an artifact of vectorinduced toxicity or inflammation, because alcohol drinking was not reduced by pHSVsiNC, which was constructed exactly like pHSVsiLA1, but does not inhibit $\alpha 1$ expression or interfere with receptor density (Figure 6D). Toxicity determined based on loss of body weight and general activity levels was not seen for pHSVsiLA1 or pHSVsiNC (Figures 7A,B).

\section{DISCUSSION}

Therapeutic strategies that target drinking-related genes may offer improved alternatives to psychosocial and pharmacotherapeutic interventions for binge drinking. Indeed, human and

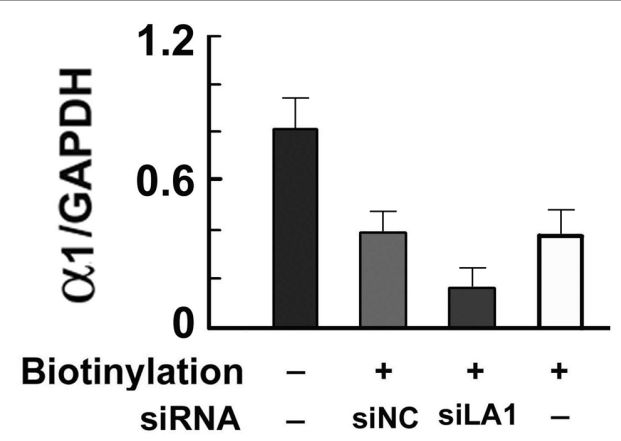

FIGURE 4 | Inhibition of biotin-labeled cell surface proteins. Eluates of WS-1 cells untreated (-) or transduced with pHSVsiLA1 or the scrambled control vector $\mathrm{pHSV}$ siNC, examined for biotinylated GABA $\alpha 1$ protein by immunoblotting. Approximately $50 \%$ of the total levels of $\alpha 1$ protein expressed in the cells is biotinylated (i.e., expressed on the cell surface). Similar levels of biotinylated $\alpha 1$ protein were seen in cells treated with pHSVsiNC, but treatment with pHSVLA1 caused a significant decrease in the levels of biotinylated $\alpha 1$ protein $[F(3,8)=316.78, P<0.001]$.

Subsequent Tukey post hoc test confirmed that inhibition of $\alpha 1$ expression by pHSVsiLA1 also caused a significant reduction in the levels of cell surface protein expression $(P<0.01)$. animal studies, including studies focusing on the contribution of the $\mathrm{GABA}_{\mathrm{A}}$ receptor (Edenberg et al., 2004; Dick et al., 2006) have shown that genetics are a strong risk factor for alcoholism (Cloninger, 1987; McBride and Li, 1998; Murphy et al., 2002). However, major clinical challenges are posed by our relatively poor understanding of the role played by specific subunits in the regulation of excessive alcohol drinking and the brain loci in which they are expressed (June and Eiler, 2007; Lobo and Harris, 2008). Following our previous report for P rats (Liu et al., 2011), the current findings provide a second piece of compelling molecular evidence that overexpression of the $\mathrm{GABA}_{\mathrm{A}} \alpha 1$ subunit within distinct neuroanatomical loci plays a key role in the regulation of binge drinking, suggesting that its inhibition with vector-delivered siRNA may have therapeutic potential. The following comments seem pertinent with respect to these findings.

An emerging hypothesis is that addiction results from the interaction of reward mechanisms and impaired inhibition of regulatory genes (Goldstein and Volkow, 2002; De Wit and Richards, 2004), such as the $\mathrm{GABA}_{\mathrm{A}}$ receptor. However, the exact identity of the contributing receptor subunit and its localization in the brain are still unknown. Our data indicate that the levels of the $\mathrm{GABA}_{\mathrm{A}}$ $\alpha 1$ subunit are significantly elevated in the VP of HAD animals relative to their LAD counterparts, and that siRNA-mediated inhibition of $\alpha 1$ expression in the VP reduces both receptor density and binge alcohol drinking. The specificity of the siRNA used in these studies and the HSV-1-based amplicon vector used for its delivery (pHSVsiLA1) were documented by direct comparison of the effects of pHSVsiLA1 to those mediated by an identical vector used to deliver a scrambled siRNA sequence (pHSVsiNC) in cultured cells that specifically overexpress only the $\alpha 1$ subunit (Liu et al., 2011) and in brains from microinfused rats (Figure 6D). In all our studies, pHSVsiNC had no effect on $\alpha 1$ expression, receptor density, or alcohol intake. This is in contrast to pHSVsiLA1, which caused a profound and selective reduction of the $\alpha 1$ protein levels, the density of the $\mathrm{GABA}_{\mathrm{A}}$ receptor and alcohol drinking. The specificity of the effect of pHSVsiLA1 is further documented by the finding that pHSVsiLA1 failed to alter $\alpha 2$ protein levels. Expression of the $\alpha 1$ gene in the VP was maximally reduced at 3 days after pHSVsiLA1 microinfusion. At that time, the VP evidenced approximately $60 \%$ reduction in radioligand binding using $\left[{ }^{3} \mathrm{H}\right] \mathrm{EBOB}$, with no significant change in affinity between
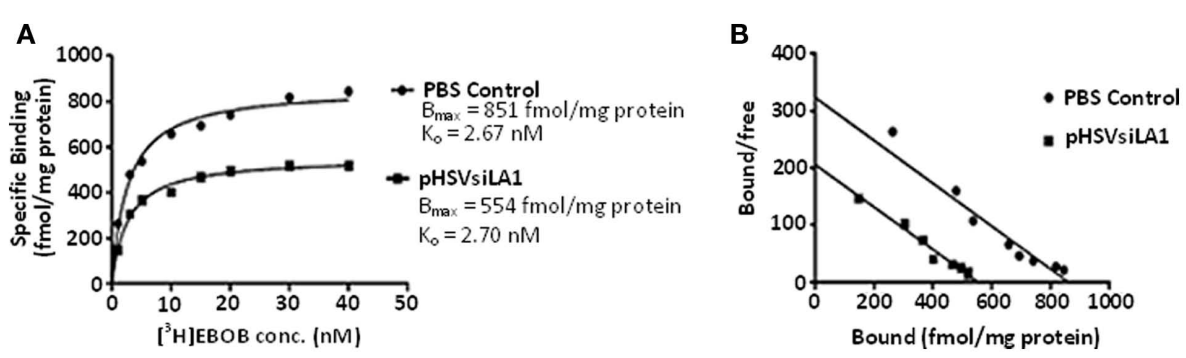

FIGURE 5 | Binding profile of $\left[{ }^{3} \mathrm{H}\right] \mathrm{EBOB}$ in HAD rats microinfused with PBS $(n=10)$ or pHSVsiLA1 $(n=10)$ at $\mathbf{7 2}$ h post-infusion. (A) Saturation isotherm shows significant differences in specific binding between the two groups $[F(3,312)=107, P<0.0001]$. A Tukey post hoc test detected that $\left[{ }^{3} \mathrm{H}\right]$ EBOB binding (B max) was reduced from $861 \pm 16$ to $554 \pm 8 \mathrm{fmol} / \mathrm{mg}$ protein in control and pSHVsiLA1-treated rats, respectively, with no significant change in affinity $\left(K_{\mathrm{d}}\right.$; control, $2.67 \pm 0.24 \mathrm{nM}$;

pHSVsiLA1-treated, $2.70 \pm 0.18 \mathrm{nM})$. (B) Scatchard analysis of $\left[{ }^{3} \mathrm{H}\right] \mathrm{EBOB}$ binding to $\mathrm{GABA}_{\mathrm{A}}$ receptors in VP of PBS- $(n=10)$ or pHSVsiLA1- $(n=20)$ treated rats. 

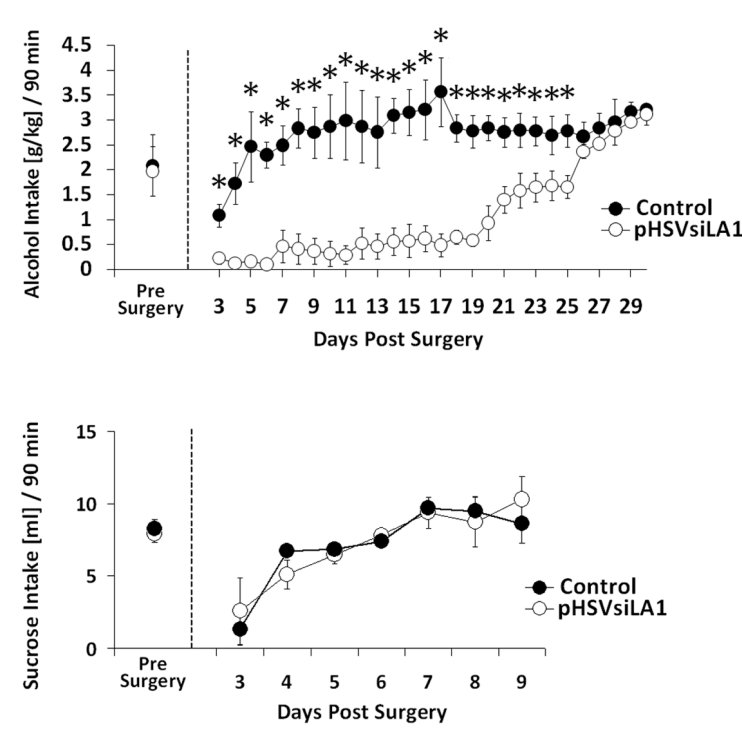

FIGURE 6 | pHSVsiLA1 delivery into the VP inhibits alcohol intake in HAD rats. (A-C) HAD rats were microinfused with pHSVsiLA1 $(n=6)$ or PBS (control; $n=6)$ into the VP and examined for intake of alcohol $(10 \% \mathrm{~V} / \mathrm{V})(\mathbf{A})$, water (B), or sucrose (C) in a home-cage bottle paradigm for $90 \mathrm{~min}$. Alcohol results are expressed in grams per kilogram $(\mathrm{g} / \mathrm{kg})$. Prior to surgery, BACs in the PBS control and pHSVsiLA1 groups were $112 \mathrm{mg} \% / \mathrm{dL} \pm 13$ and $118 \mathrm{mg} \% / \mathrm{dL} \pm 25$, respectively. Two-way ANOVA revealed significant main effects of Day $[F(28,140)=5.58, P<0.001]$, Group $[F(1,5)=86.184$, $P<0.001]$, and a significant interaction for Day $\times \operatorname{Group}[F(28,140)=5.35$, $P<0.001$ ]. Relative to the control group, significant reductions in alcohol drinking were observed in the pHSVsiLA1-treated group from days 3-25 (Tukey post hoc test). Alcohol intake was similar during days 26-30 for the pHSVsiLA1 and PBS control groups. (B) Water intake $(\mathrm{mL} / \mathrm{kg}) / 22.5 \mathrm{~h}$ was also similar across pre-surgical days and post-surgical days 1-10 between the pHSVsiLA1 and PBS control groups. (C) Sucrose intake in the two-bottle choice home-cage paradigm over the 90 -min period. ANOVA revealed a
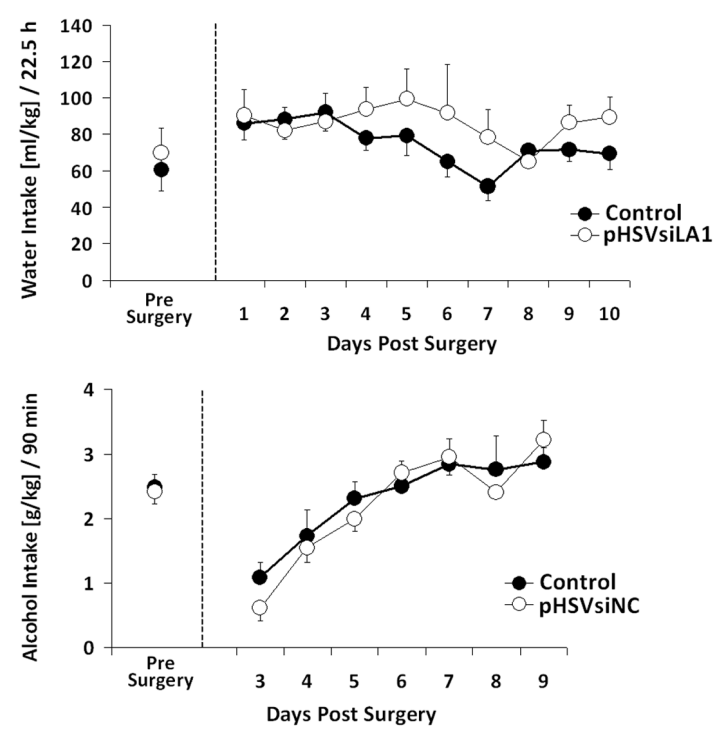

significant session effect $[F(7,74)=3.616, P<0.0001]$. Specifically, both the control and pHSVsiLA1 pre-surgery groups demonstrated significantly higher drinking than the post-surgery groups on day $3(P<0.01)$. However, no differences were observed between the two groups at pre-surgery or at any post-surgery time point $(P>0.01)$. (D) HAD rats were given the scrambled amplicon pHSVsiNC ( $n=6$ ) or PBS (control; $n=6$ ) into the VP and examined for alcohol consumption. Results are expressed in grams per kilogram $(\mathrm{g} / \mathrm{kg}$ ) during the daily $90 \mathrm{~min}$ alcohol sessions. Prior to surgery, BACs in the PBS and $\mathrm{pHSV}$ siNC groups were $133 \mathrm{mg} \% / \mathrm{dL} \pm 26$ and $122 \mathrm{mg} \% / \mathrm{dL} \pm 21$, respectively. ANOVA revealed a significant session effect $[F(7,80)=11.96$, $P<0.0001$ ], but no group effects. Specifically, drinking in the both the control and pHSVsiNC pre-surgery groups was significantly greater than in the post-surgery groups on days 3 and $4(P<0.01)$. However, no differences were observed between the two groups at pre-surgery or at any post-surgery time point $(P>0.01)$. Significant effects were identified using the Newman-Keuls post hoc test. the control- and pHSVsiLA1-treated groups $\left(K_{\mathrm{d}}=2.67 \pm 0.24\right.$ vs. $2.70 \pm 1.8 \mathrm{nM}$, respectively). In this context, it is important to point out that the magnitude of binding using $\left[{ }^{3} \mathrm{H}\right] \mathrm{EBOB}$ correlated with $\alpha 1$ expression on the cell surface, as determined by biotinylation analysis of pHSVsiLA1-treated cultured cells. Interestingly, temporal studies of the pHSVsiLA1-treated rats indicated that $\alpha 1$ expression in the VP was still inhibited at 17 days postinfusion, albeit at a less robust level than that seen for day 3 post-infusion. This is indicative of a time-dependent restoration of $\alpha 1$ gene expression. Indeed, by day 30 post-infusion, the levels of $\alpha 1$ expressed in the VP from the pHSVsiLA1-treated rats were similar to those seen in the same animals before microinfusion (pre-surgery), as well as those in PBS and pHSVsiNC-treated rats throughout the study interval. Most importantly, alcohol intake by the HAD rats showed a very strong correlation with $\alpha 1$ expression in the VP, with drinking being inhibited throughout the time that $\alpha 1$ expression was reduced and returning to baseline levels together with $\alpha 1$ expression. While we still do not know the exact time after day 17 at which $\alpha 1$ expression was restored, the protracted duration of pHSVsiLAl's effect is consistent with previous reports for the function of siRNA delivered with HSV amplicons (Saydam et al., 2005) and suggests that this approach may have therapeutic promise. The behavioral data across the 30-day time period (Figure 6A) show that, by day 21, profound elevations in drinking begin to emerge, with a daily progression in intake being observed up to the conclusion of the 30-day intake period. We lack protein data for days 18-29; however, the data we do have support the elevations seen in drinking and show the protein levels progressing in the same direction as the behavior.

The precise mechanism by which $\mathrm{GABA}_{\mathrm{A}}$ receptors in the VP contribute to the regulation of alcohol intake is still unclear. It is possible that elevations in protein expression in the VP and other alcohol reward loci results in an overactive GABAergic/dopaminergic reward circuitry. This, in turn, may predispose alcoholics to engage in binge drinking by altering impulsivity (Edenberg et al., 2004). Indeed, impulsivity is associated with excessive drinking in humans (Petry, 2001) and rodents (Wilhelm and Mitchell, 2008; Oberlin and Grahame, 2009), particularly with binge drinking (Stephens and Duka, 2008). Recently, it has been shown that elevated dopamine levels also play a significant role in modulating impulsivity (Buckholtz et al., 2010; Fernando et al., 2011). Thus, it is possible that the elevated GABA levels in $\mathrm{P}$ rats may disinhibit dopaminergic neurons in the VP (Kalivas, 


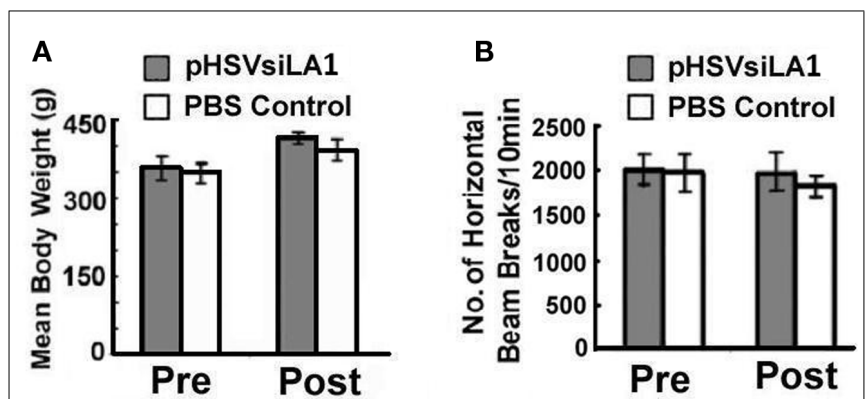

FIGURE 7 | Amplicon vectors do not alter body weight or locomotor activity measurements in the open-field in HAD rats. (A) Body weights and locomotor measures for animals given pHSVsiLA1 or PBS control $n=8$ each/total $=16$ ) at $96 \mathrm{~h}$ post-surgery (4 days). No significant differences were observed between groups for body weight $[F(3,28)=0.252$, $P>0.05$ ]. (B) In addition, locomotor activity (i.e., horizontal activity over a 10 -min period) was also similar for animals given PBS and pHSVsiLA1 ( $n=8$ each/total $=16)$ at $96 \mathrm{~h}$ post-surgery $(4$ days) $[F(3,28)=0.0278, P>0.994]$ No significant differences between groups were observed.

1993). Such elevations in dopamine could result in reductions in alcohol self-administration following siRNA microinfusion into the VP.

GABAergic neurons in the VP have been reported to regulate major dopaminergic output neurons within the same structure (Gong et al., 1998). It has also been reported that the VP receives additional GABAergic afferents from the VTA (Kalivas, 1993), which is also been known to regulate excessive alcohol drinking (McBride and Li, 1998; Eiler II and June, 2007). GABA can directly inhibit or indirectly stimulate dopaminergic cells via disinhibition of GABAergic interneurons (Kalivas, 1993). Thus, the topography of the VP places it in a unique position to serve as a pivotal regulator of dopaminergic and GABAergic inputs that could control binge drinking. The relationship between enhanced GABA levels and excessive alcohol drinking has also been demonstrated (Roberto et al., 2004). In this context, it is particularly important to point out that pHSVsiLA1-mediated inhibition of $\alpha 1$ in the NAcc and CeA does not reduce alcohol intake in $\mathrm{P}$ rats (Liu et al., 2011). In contrast, inhibition of $\alpha 2$ in the CeA reduces binge drinking (Liu et al., 2011). Thus, the current data and our prior research strongly suggest that neuroanatomical localizations of the $\alpha 1$ and $\alpha 2$ receptor subunits in the VP and CeA, respectively, are key regulators of binge drinking.

In conclusion, taken together, our data suggest that binge drinking is due in part to impairment of neuronal inhibition caused by an overactive GABAergic reward circuitry. While normal GABAergic tone may dampen impulsivity to impair the initiation of binge drinking (Edenberg et al., 2004), elevations in certain brain reward loci may release the inhibition of neuronal activity to initiate the behavior. More research is needed to further delineate the role that an overactive GABAergic reward circuitry plays in binge drinking.

\section{MATERIALS AND METHODS ANTIBODIES}

The generation and specificity of the rabbit-derived $\mathrm{GABA}_{\mathrm{A}} \alpha 1$ and $\alpha 2$ antibodies have been described previously (Pirker et al., 2000). These recognize amino acids $1-9$ and $322-357$ of the $\alpha 1$ and $\alpha 2$ proteins, respectively. The antibody controls (GAPDH and actin) can be used interchangeably, based on availability. The GAPDH antibody was unavailable during the middle portion of the study period.

\section{AMPLICON CONSTRUCTION AND CELL TRANSDUCTION}

The siRNAs LA1 ( $\alpha 1$ subunit) and NC (scrambled, non-specific), as well as the construction and functionality of the respective HSV1-based amplicon vectors, are described in Table S1 and Figures S2-S4 in Supplementary Material (Liu et al., 2011). Construction used the basic plasmid pHSVsi that contains an HSV-1 origin of DNA replication (ori), the HSV-1 DNA packaging/cleavage signal (pac), and the HSV-1 IE 4/5 promoter to express the EGFP reporter gene. A second transcription unit consists of the RNA polymerase III-dependent $\mathrm{H} 1$ promoter and start and termination signals for siRNA synthesis (Saydam et al., 2005). The siRNAs were inserted into pHSVsi between the BglII and HindIII sites. Amplicon DNA was packaged into HSV-1 particles and the titers of the vector stocks were determined by counting the number of green cells at $24 \mathrm{~h}$ after transduction and expressing them as transduction units (TU)/mL.

\section{IMMUNOBLOTTING}

Ventral pallidum tissues were harvested by micropunch $(140 \mu \mathrm{m}$ thick). Immunoblotting was conducted as previously described (Wales et al., 2007). Lysis was performed in RIPA buffer $(20 \mathrm{mM}$ Tris- $\mathrm{HCl}$ ( $\mathrm{pH} 7.4$ ), $0.15 \mathrm{mM} \mathrm{NaCl}, 1 \%$ Nonidet P-40, $0.1 \%$ sodium dodecyl sulfate, $0.5 \%$ sodium deoxycholate) with $1 \%$ phosphatase and protease inhibitor cocktails (Sigma, St. Louis, MO, USA), and total protein was determined by the bicinchoninic assay (Pierce, Rockford, IL, USA). Proteins were resolved by sodium dodecyl sulfate-polyacrylamide gel electrophoresis and transferred to nitrocellulose membranes. Blots were exposed to antibody overnight at $4^{\circ} \mathrm{C}$, followed by horseradish peroxidase-labeled goat anti-rabbit IgG (Cell Signaling, Beverly, MA, USA) for $1 \mathrm{~h}$ at room temperature. Detection was performed using ECL kit reagents (Amersham Life Science, Arlington Heights, IL, USA) and quantitation was by densitometric scanning with a Bio-Rad GS-700 imaging densitometer.

\section{RADIOLIGAND BINDING}

Cerebellum, VP, CeA, and BST membrane homogenates were prepared from adult male HAD rats, and binding of $\left[{ }^{3} \mathrm{H}\right] \mathrm{EBOB}$ was determined by filtration assay (Kralic et al., 2002). Briefly, homogenates were incubated with $6.0 \mathrm{nM}\left[{ }^{3} \mathrm{H}\right] \mathrm{EBOB}$ in $50 \mathrm{mM}$ Tris- $\mathrm{HCl}$ buffer ( $\mathrm{pH} 7.4$ ), containing $300 \mathrm{mM} \mathrm{NaCl}$, at $23^{\circ} \mathrm{C}$ for $1 \mathrm{~h}$. Non-specific binding was determined with $50 \mu \mathrm{M}$ picrotoxin. After incubation, bound and free ligand were separated by rapid filtration over Whatman GF/B glass-fiber filters (presoaked in $0.05 \%$ polyethylenimine for $20 \mathrm{~min}$ ), followed by three $4 \mathrm{~mL}$ washes with ice-cold $0.9 \% \mathrm{NaCl}$ solution. Radioactivity was counted by liquid scintillation spectroscopy (Packard TRI-CARB 2900 TR, Downers Grove, IL, USA).

\section{ISOLATION OF BIOTIN-LABELED CELL SURFACE PROTEINS}

To examine whether $\mathrm{pHSV}$ siLA1 alters the expression of the GABA $\alpha 1$ protein on the cell surface, we used the Pierce ${ }^{\circledR}$ Cell Surface Protein Isolation Kit (Pierce Biotechnology, Rockford, IL, USA) according to the manufacturer's instructions. 


\section{STEREOTAXIC PROCEDURES}

High-alcohol drinking rats were anesthetized by intraperitoneal injection of nembutal $(50 \mathrm{mg} / \mathrm{kg})$ and positioned in a stereotaxic apparatus as described previously (Liu et al., 2011). The selected microinjection sites in the rat $\mathrm{VP}$ extend from $+2.2 \mathrm{~mm}$ anterior to bregma to $-0.8 \mathrm{~mm}$ posterior to bregma, and from 0.5 to $3.0 \mathrm{~mm}$ lateral to the midline (Paxinos and Watson, 1998). Since amplicons do not diffuse over long distances in brain, a single large injection would fail to cover the entire VP and likely also result in a pressure lesion. Thus, we performed a pattern of 13 small injections in each hemisphere spaced across the entire VP (Figure 2B). At each site, $200 \mathrm{~nL}$ of either pHSVsiLA1 amplicon $\left(2.5 \times 10^{5} \mathrm{TU}\right)$, pHSVsiNC $\left(2.5 \times 10^{5} \mathrm{TU}\right)$ in PBS diluent or PBS control were injected using a calibrated pulled glass micropipette $(\sim 20 \mu \mathrm{m}$ tip) connected to a Picospritzer II pneumatic pressure injection apparatus (Science Products $\mathrm{GmbH}$, Hofheim, Germany). Injections lasted $30 \mathrm{~s}$ and were separated by $1-2 \mathrm{~min}$ pauses for tissue recovery prior to insertion of the pipette at the next site. Acrylic microbeads were mixed with the amplicon and control injections to confirm accuracy of the microinjection placement based on the Rat Brain Atlas (Paxinos and Watson, 1998). All surgical and amplicon administration procedures were approved by the IACUC and Biosafety Committees at the University of Maryland School of Medicine.

\section{BINGE ALCOHOL DRINKING}

To initiate excessive alcohol drinking in HAD rats, we used the drinking-in-the-dark-multiple-scheduled-access (DIDMSA) binge model developed by the Integrative Neuroscience Initiative on Alcoholism (INIA)-West, 2008, McBride and Li, 1998, Bell et al., 2006, which emulates the binge alcohol drinking patterns seen in humans (Naimi et al., 2003). Our experimental design comprised both pre- and post-surgery phases of home-cage binge alcohol drinking. In brief, rats were each presented with two $10 \mathrm{~mL}$ glass pipette vials equipped with stainless-steel sipper spouts and rubber stoppers. The pipettes were calibrated to allow for measurement

\section{REFERENCES}

Bell, R. L., Rodd, Z. A., Lumeng, L., Murphy, J. M., and McBride, W. J. (2006). The alcohol-preferring $p$ rat and animal models of excessive alcohol drinking. Addict. Biol. 11, 270-288.

Boehm, S. L. II, Ponomarev, I., Jennings, A. W., Whiting, P. J., Rosahl, T. W., Garrett, E. M., Blednov, Y. A., and Harris, R. A. (2004). Gammaaminobutyric acid A receptor subunit mutant mice: new perspectives on alcohol actions. Biochem. Pharmacol. 68, 1581-1602. [Review].

Buckholtz, J. W., Treadway, M. T., Cowan, R. L., Woodward, N. D., Li, R., Ansari, M. S., Baldwin, R. M., Schwartzman, A. N., Shelby, E. S., Smith, C. E., Kessler, R. M., and Zald, D. H. (2010). Dopaminergic network differences in human impulsivity. Science 29, 532.

of drinking for both alcohol and water. The $10 \%(\mathrm{v} / \mathrm{v})$ alcohol solution was prepared using 10\% alcohol (USP) and $90 \%$ deionized water $(\mathrm{v} / \mathrm{v})$. This pre-surgery phase included 21 days of consecutive alcohol drinking wherein HAD rats consumed alcohol for $1.5 \mathrm{~h}$ daily. The daily $1.5 \mathrm{~h}$ alcohol drinking periods were each divided into three $30 \mathrm{~min}$ bouts separated by $1 \mathrm{~h}$ intervals wherein rats received food and water in their home cages. During the non-binge periods (i.e., $22.5 \mathrm{~h}$ ), rats also received food and water ad libitum. To determine if the rats were consuming binge alcohol levels of the $10 \%(\mathrm{v} / \mathrm{v})$ alcohol solution, BAC levels were evaluated beginning on day 11 of the pre-surgery period, and were quantified every other day up to day 21 , as previously reported (Harvey et al., 2002). Based on quantification of BACs, the HAD rats were stratified into two cohorts with BACs of $112 \mathrm{mg} \% / \mathrm{dL} \pm 13(n=6)$ or $118 \mathrm{mg} \% / \mathrm{dL} \pm 25(n=5)$. The two cohorts then received the PBS control or the pHSVsiLA1 amplicon vector, respectively. Seventytwo hours after administration of the experimental treatments, the post-surgery phase began. During the post-surgery phase, all rats consumed their daily $1.5 \mathrm{~h}$ binge alcohol for 15 consecutive days.

\section{STATISTICAL ANALYSES}

Data were analyzed by between-group ANOVAs and mixed repeated-measures ANOVAs for group and days. Significant ANOVAs were followed by the Tukey, Newman-Keuls or $t$-test post hoc tests. Analyses were performed using the StatMost 5.0 (Dataxiom Software Inc., Los Angeles, CA, USA) and GraphPad Prism 6.0 (GraphPad Software, Inc., La Jolla, CA, USA) programs.

\section{ACKNOWLEDGMENTS}

This research was supported by NIAAA grants R21AA016933 and R01AA017963 to Harry L. June and NINDS, National Institutes of Health (NIH) public health service grant NS45169 to Laure Aurelian. We are grateful to Dr. Cynthia Smith for help with the siRNA studies and Istvan Merchenthaler for assisting with the binding study.

greater brain damage in alcoholpreferring $\mathrm{P}$ rats than in alcoholnonpreferring NP rats. Alcohol. Clin. Exp. Res. 27, 1075-1082.

Criswell, H. E., Simson, P. E., Knapp, D. J., Devaud, L. L., McCown, T. J., Duncan, G. E., Morrow, A. L., and Breese, G. R. (1995). Effect of zolpidem on gammaaminobutyric acid (GABA)-induced inhibition predicts the interaction of ethanol with GABA on individual neurons in several rat brain regions. J. Pharmacol. Exp. Ther. 19, 910-914.

De Wit, H., and Richards, J. B. (2004). Dual determinants of drug use in humans: reward and impulsivity. Nebr. Symp. Motiv. 50, 19-55.

Devaud, L. L., Morrow, A. L., Criswell, H. E., Breese, G. R., and Duncan, G. E. (1995). Regional differences in the effects of chronic ethanol administration on $[3 \mathrm{H}]$ zolpidem binding in rat brain. Alcohol. Clin. Exp. Res. 19, 910-914.

Dick, D. M., Plunkett, J., Wetherill, L. F., Xuei, X., Goate, A., Hesselbrock, V., Schuckit, M., Crowe, R., Edenberg, H. J., and Foroud, T. (2006). Association between GABRAl and drinking behaviors in the collaborative study on the genetics of alcoholism sample. Alcohol. Clin. Exp. Res. 30, 1101-1110.

Edenberg, H. J., Dick, D. M., Xuei, X., Tian, H., Almasy, L., Bauer, L. O., Crowe, R. R., Goate, A., Hesselbrock, V., Jones, K., Kwon, J., Li, T. K., Nurnberger, J. I. Jr., O’Connor, S. J., Reich, T., Rice, J., Schuckit, M. A., Porjesz, B., Foroud, T., and Begleiter, H. (2004). Variations in GABRA2, encoding the alpha 2 subunit of the GABA(A) receptor, are associated with alcohol dependence and with brain oscillations. Am. J. Hum. Genet. 74, 705-714. 
Eiler, W. J. II, and June, H. L. (2007). Blockade of GABA(A) receptors within the extended amygdala attenuates $\mathrm{D}(2)$ regulation of alcoholmotivated behaviors in the ventral tegmental area of alcohol-preferring (P) rats. Neuropharmacology 52, 1570-1579.

Fernando, A. B., Economidou, D., Theobald, D. E., Zou, M. F., Newman, A. H., Spoelder, M., Caprioli, D., Moreno, M., Hipólito, L., Aspinall, A. T., Robbins, T. W., and Dalley, J. W. (2011). Modulation of high impulsivity and attentional performance in rats by selective direct and indirect dopaminergic and noradrenergic receptor agonists. Psychopharmacology (Berl.). [Epub ahead of print].

Goldstein, R. Z., and Volkow, N. D. (2002). Drug addiction and its underlying neurobiological basis: neuroimaging evidence for the involvement of the frontal cortex. Am. J. Psychiatry 159, 1642-1652.

Gong, W., Neill, D. B., and Justice, J. B. Jr. (1998). GABAergic modulation of ventral pallidal dopamine release studied by in vivo microdialysis in the freely moving rat. Synapse 29, 406-412.

Harris, R. A., Trudell, J. R., and Mihic, S. J. (2008). Ethanol's molecular targets. Sci. Signal. 1, re7.

Harvey, S. C., Foster, K. L., McKay, P. F., Carroll, M. R., Seyoum, R., Woods, J. E. II, Grey, C., Jones, C. M., McCane, S., Cummings, R., Mason, D., Ma, C., Cook, J. M., and June, H. L. (2002). The GABAA receptor subtype in the ventral pallidum regulates alcohol-seeking behavior. $J$. Neurosci. 22, 3765-3775.

Heimer, L., and Alheid, G. F. (1991). Piecing together the puzzle of basal forebrain anatomy. Adv. Exp. Med. Biol. 295, 1-42.

Hingson, R. W., and Zha, W. (2009). Age of drinking onset, alcohol use disorders, frequent heavy drinking, and unintentionally injuring oneself and others after drinking. Pediatrics 123 , 1477-1484.

Integrative Neuroscience Initiative on Alcoholism (INIA)-West. (2008). Drinking in the dark rat model. Available at: http://www.scripps.edu/ cnad/inia/modelratdrinkingindark. pdf

June, H. L. Sr., and Eiler, W. L. A. II. (2007). "Handbook of contemporary neuropharmacology," in Dopaminergic and GABAergic Regulation of Alcohol-Motivated Behaviors: Novel Neuroanatomical Substrates, eds D. R. Sibley, I. Hanin, M. Kuhar, P. Skolnick (Hoboken, NJ: Wiley \& Sons), 1-72.
June, H. L. Sr., Foster, K. L., Eiler, W. J. II, Goergen, J., Cook, J. B., Johnson, N., Mensah-Zoe, B., Simmons, J. O., June, H. L. Jr., Yin, W., Cook, J. M., and Homanics, G. E. (2007). Dopamine and benzodiazepine-dependent mechanisms regulate the EtOH enhanced locomotor stimulation in the GABA $_{\mathrm{A}}$ alphal subunit null mutant mice. Neuropsychopharmacology 32, 137-152.

June, H. L. Sr., Foster, K. L., McKay, P. F., Seyoum, R., Woods, J. E., Harvey, S. C., Eiler, W. J., Grey, C., Carroll, M. R., McCane, S., Jones, C. M., Yin, W., Mason, D., Cummings, R., Garcia, M., Ma, C., Sarma, P. V., Cook, J. M., and Skolnick, P. (2003). The reinforcing properties of alcohol are mediated by $\mathrm{GABA}(\mathrm{Al})$ receptors in the ventral pallidum. Neuropsychopharmacology 28, 2124-2137.

Kalivas, P. W. (1993). Neurotransmitter regulation of dopamine neurons in the ventral tegmental area. Brain Res. Brain Res. Rev. 18, 75-113.

Kaufmann, W. A., Humpel, C., Alheid, G. F., and Marksteiner, J. (2003). Compartmentation of alpha 1 and alpha 2 GABA(A) receptor subunits within rat extended amygdala: implications for benzodiazepine action. Brain Res. 964, 91-99.

Koob, G. F. (2004). A role for GABA mechanisms in the motivational effects of alcohol. Biochem. Pharmacol. 68, 1515-1525.

Koob, G. F., and Le Moal, M. (2005). Plasticity of reward neurocircuitry and the 'dark side' of drug addiction. Nat. Neurosci. 8, 1442-1444.

Korpi, E. R., Herb, A., and Lüddens, H. (1995). Effects of ethanol on recombinant rat GABAA receptors: [35S]tbutylbicyclophosphorothionate ([35S]TBPS) binding study. Pharmacol. Toxicol. 77, 87-90.

Kralic, J. E., Korpi, E. R., O’Buckley, T. K., Homanics, G. E., and Morrow, A. L. (2002). Molecular and pharmacological characterization of GABAA receptor $\alpha 1$ subunit knockout mice. 302, 1037-1045.

Kumar, S., Porcu, P., Werner, D. F., Matthews, D. B., Diaz-Granados, J. L., Helfand, R. S., and Morrow, A. L. (2009). The role of $\mathrm{GABA}(\mathrm{A})$ receptors in acute and chronic effects of ethanol: a decade of progress. Psychopharmacology (Berl.) 205, 529-564.

Liu, J., Yang, A. R., Kelly, T., Puche, A., Esoga, C., June, H. L. Jr., Elnabawi, A., Merchenthaler, I., Sieghart, W., June, H. L. Sr., and Aurelian, L. (2011). Binge alcohol drinking is associated with GABAA \{alpha\}2regulated Toll-like receptor 4 (TLR4) expression in the central amygdala. Proc. Natl. Acad. Sci. U.S.A. 108 4465-4470.

Lobo, I. A., and Harris, R. A. (2008). GABA(A) receptors and alcohol. Pharmacol. Biochem. Behav. 90, 90-94.

McBride, W. J., and Li, T. K. (1998) Animal models of alcoholism: neurobiology of high alcohol-drinking behavior in rodents. Crit. Rev. Neurobiol. 12, 339-369.

Murphy, B. C., Chiu, T., Harrison, M., Uddin, R. K., and Singh, S. M. (2002). Examination of ethanol responsive liver and brain specific gene expression, in the mouse strains with variable ethanol preferences, using cDNA expression arrays. Biochem. Genet. 40, 395-410.

Naimi, T. S., Brewer, R. D., Mokdad, A., Denny, C., Serdula, M. K., and Marks, J. S. (2003). Binge drinking among US adults. JAMA 289, 70-75.

National Institute on Alcohol Abuse, and Alcoholism. (2004). NIAAA Council approves definition of binge drinking. NIAAA Newsl. 04-5346, 3.

National Survey on Drug Use and Health. (2002). Overview of Findings: 2002 National Survey on Drug Use and Health (NSDUH). SAMHSA, Office of Applied Studies. Available at: www.oas.samhsa.gov/ nhsda/2k2nsduh/ overview/ ekeOverview.htm [accessed April 09, 2011].

Oberlin, B. G., and Grahame, N. J. (2009). High-alcohol preferring mice are more impulsive than lowalcohol preferring mice as measured in the delay discounting task. Alcohol. Clin. Exp. Res. 33, 1294-1303.

Paxinos, G., and Watson, C. (1998). The Rat Brain in Stereotaxic Coordinates, 4th Edn. San Diego: Academic Press.

Petry, N. M. (2001). Substance abuse, pathological gambling, and impulsiveness. Drug Alcohol Depend. 63 29-38.

Pirker, S., Schwarzer, C., Wieselthaler, A. Sieghart, W., and Sperk, G. (2000). GABA(A) receptors: immunocytochemical distribution of 13 subunits in the adult rat brain. Neuroscience 101, 815-850.

Roberto, M., Madamba, S. G., Stouffer, D. G., Parsons, L. H., and Siggins, G. R. (2004). Increased GABA release in the central amygdala of ethanol-dependent rats. J. Neurosci. 24, 10159-10166.

Saydam, O., Glauser, D. L., Heid, I. Turkeri, G., Hilbe, M., Jacobs, A. H., Ackermann, M., and Fraefel,
C. (2005). Herpes simplex virus 1 amplicon vector-mediated siRNA targeting epidermal growth factor receptor inhibits growth of human glioma cells in vivo. Mol. Ther. 12, 803-812.

Smith, S. S., Gong, Q. H., Hsu, F. C., Markowitz, R. S., French-Mullen, J. M., and Li, X. (1998). GABA(A) receptor alpha4 subunit suppression prevents withdrawal properties of an endogenous steroid. Nature 392, 926-930.

Stephens, D. N., and Duka, T. (2008). Cognitive and emotional consequences of binge drinking: role of amygdala and prefrontal cortex. $P h i-$ los. Trans. R. Soc. Lond. B Biol. Sci. 363, 3169-3179.

Townshend, J. M., and Duka, T. (2005). Binge drinking, cognitive performance and mood in a population of young social drinkers. Alcohol. Clin. Exp. Res. 29, 317-325.

Wales, S. Q., Li, B., Laing, J. M., and Aurelian, L. (2007). The herpes simplex virus type 2 gene ICP10PK protects from apoptosis caused by nerve growth factor deprivation through inhibition of caspase- 3 activation and XIAP up-regulation. J. Neurochem. 103, 365-379.

Wilhelm, C. J., and Mitchell, S. H. (2008). Rats bred for high alcohol drinking are more sensitive to delayed and probabilistic outcomes. Genes Brain Behav. 7, 705-713.

Conflict of Interest Statement: The authors declare that the research was conducted in the absence of any commercial or financial relationships that could be construed as a potential conflict of interest.

Received: 17 May 2011; accepted: 27 September 2011; published online: 18 October 2011.

Citation: Yang ARST, Liu J, Yi HS, Warnock KT, Wang M, June HL Jr., Puche AC, Elnabawi A, Sieghart W, Aurelian L and June HL Sr. (2011) Binge drinking: in search of its molecular target via the $G A B A_{A}$ receptor. Front. Neurosci. 5:123. doi: 10.3389/fnins.2011.00123

This article was submitted to Frontiers in Neuropharmacology, a specialty of Frontiers in Neuroscience.

Copyright (C) 2011 Yang, Liu, Yi, Warnock, Wang, June, Puche, Elnabawi, Sieghart, Aurelian and June. This is an open-access article subject to a nonexclusive license between the authors and Frontiers Media SA, which permits use, distribution and reproduction in other forums, provided the original authors and source are credited and other Frontiers conditions are complied with. 